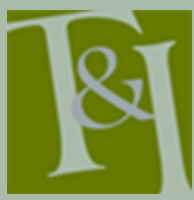

The International Journal for Translation \& Interpreting Research trans-int.org

\title{
Getting organized to beat Babel in multilingual service encounters: The European Network for Public Service Interpreting and Translation (ENPSIT)
}

\author{
Pascal Rillof \\ European Network for Public Service Interpreting and Translation (ENPSIT) \\ pascal.rillof@kruispuntmi.be
}

\section{Lieven Buysse}

KU Leuven (University of Leuven)

lieven.buysse@kuleuven.be

DOI: 10.12807/ti.107203.2015.a13

\begin{abstract}
People are on the move, coming in from beyond the borders of the European Union and circulating within it. Our major cities in particular are rapidly becoming "super-diverse" communities with many different (cultural) minorities. Many immigrant groups are, at least in the initial phase of their residence in a new community, often unable to communicate effectively in the official language. This poses important challenges for public service providers, who ought to be able to ensure equal access to their services to anyone who requires them. Yet, not all public service providers in Europe are prepared or equipped to operate in such a multilingual environment, and in many countries both comprehensive policies and structural funding are still lacking. As a result, public service interpreting and translation are available and made use of very unevenly. Following earlier initiatives to put public service interpreting and translation (PSIT) on the agendas of the European Commission and EU member states, such as the report drawn up by the European Language Council's Special Interest Group on Translation and Interpreting for Public Services (SIGTIPS) in 2011, more recently the European Network for Public Service Interpreting and Translation (ENPSIT) was founded. Its main aims are to have the right to high-quality language assistance in service contexts officially recognized, and to see the development of (harmonized) public service interpreter and translator training, assessment and accreditation across the EU. This paper sketches (i) the societal framework within which PSIT provision is organized, (ii) how ENPSIT wishes to deploy strategies to influence European and national policy-making as well as foster excellent PSIT training and quality assurance, and (iii) how the fight for optimal communication in public services is not, nor should be, restricted to improving PSIT.
\end{abstract}

Keywords: public service interpreting, public service translation, super-diversity, multilingualism

\section{Introduction}

The training and certification of public service interpreters and translators, and the provision of their services, are not structurally embedded in EU member states' policies nor in EU policy. Public service interpreting and translation (henceforth PSIT) services are usually not funded at all or they are made available only through insecure project funds. When the final report of the European Language Council's Special Interest Group on Translation and Interpreting for the Public Service was published in 2011 (SIGTIPS, 2011), the then Commissioner for Education, Culture, Youth and Multilingualism, 
Androulla Vassiliou, wrote the preface as just one of the Commission's tokens of its awareness that PSIT could or should be placed more prominently on the European and member states' agendas.

A major stumbling block has always been that EU policy makers (most notably the European Commission) has had no central agency responsible for PSIT-related matters. The opposite also holds true: PSIT is present in so many policy domains that no single European Commission "desk" takes responsibility for it. Moreover, European initiatives can only be successful if they are based sufficiently on hard data, but to date the Commission has had no ready access to facts or figures to inform policy on PSIT as such data are scattered across various domains and countries. Such a concerted effort to collect relevant data can only be effective if the data are gathered from all over the EU and from all relevant domains.

Some 25 professionals from different countries of the European Union and other European countries gathered in Brussels on 3 and 4 October 2013 to analyse this situation, sketch a possible plan for action, and outline what was soon to become the European Network for Public Service Interpreting and Translation (ENPSIT). This organization has now been formalized and has taken its first steps to gather data, devise strategies to prepare policy-making, and develop initiatives in PSIT training and accreditation. The DirectorateGeneral for Interpretation of the EU is working with ENPSIT to map the needs of the sector and to help coordinate efforts inside the European Commission, including collecting and publishing data on PSIT. The Directorate-General for Translation - indeed a directorate in its own right - is showing an active interest as well.

This paper outlines the main developments in European society that have sparked the (ever greater) need for PSIT, and have given it such high prominence that PSIT is no longer felt to be "nice to have" but rather an absolute necessity for those involved in public service settings in which one of the participants is insufficiently familiar with the official language being used. These developments are a major part of ENPSIT's framework of reference. In Section 1 we will define what we mean by public service interpreting and translation. Section 2 sketches the changed nature of migration, while section 3 elaborates how PSIT fits into the inclusive measures that are, or should be, part and parcel of a democracy. In Section 4 we will present ENPSIT, its objectives and plan of action, before, in section 5, we place it in a broader framework of instruments available to public service providers to bridge the communication gap with their clients. In section 6 we provide a brief conclusion.

\section{Definitions}

There is no shortage of terms in the field, the most common of which seem to be community interpreting, public services interpreting, liaison interpreting and dialogue interpreting in English (Bancroft, Bendana, Bruggeman, \& Feuerle, 2013, p. 95). Other languages add their own variants such as sociaal tolken en vertalen (social interpreting and translation) in Dutch, or interprétariat et traduction en milieu social in French. In recent years the terms that have received widest currency are probably community interpreting and public service interpreting. ENPSIT decided to opt for the latter term because it was considered to have the broadest scope, reflected present-day reality in the profession, and tied in with the practice established by the European Language Council's special interest group (SIGTIPS, 2011) among others. We might add that many definitions of community interpreting explicitly mention public service provision or providers as the actor commissioning the intervention of an interpreter (see e.g. definitions listed by Taibi, 2014). Again similar to SIGTIPS practice, ENPSIT does not restrict its scope to interpreting but includes 
translation as well, simply because there is a real need of translation services for written documents in public service contexts (see also D'Hayer, 2012, p. 238).

For the purposes of this paper, we shall define public service interpreting in Pöchhacker's (1999) terms as "interpreting in institutional settings of a given society in which public service providers and individual clients do not speak the same language"1 $(1999$, p. 126). In a similar vein, public service translation involves the translation of written texts in these same contexts. The most obvious differences are that the messages being conveyed are written and in many cases a dialogue (in the broad sense of the word) is absent. Documents may be of an official nature (acts, driver's licenses, identity papers, diplomas, etc.), or rather aimed at transferring information between the service providers and the client (e.g. letters, appointment notifications, medical reports, leaflets supporting health or prevention campaigns, etc.).

\section{The changed nature of migration}

In his essay "The condition we call exile" Joseph Brodsky states: "Displacement and misplacement are this century's commonplace" (Brodsky, 1988, p. 16). He was obviously writing about the previous century, but his words have not lost their significance. Since 1990 the nature of migration has changed. Europe has become "super-diverse", a neologism coined by Vertovec (2007) for the rapidly changing constellation of Europe's population. No longer do we only see an influx of the traditional groups of immigrant workers and their families into EU member states and their major cities. Rather, people are arriving from just about everywhere, and immigration is not confined to large cities anymore. Immigrants are pushed by meagre subsistence and poor prospects of advancement, environmental decay and disaster, and conflict. They are pulled by the hope of bettering their own lives as well as their children's.

Two factors seem to have been dominant in the changing face of migration over the past few decades, and both are of a global nature. The first is the fall of the iron curtain and its immediate ramifications in terms of free movement in 1989-1990, making migration from Eastern Europe possible and to a certain extent legal. A second, simultaneous development was economic and social globalization, spurred on by the IT revolution, which made the internet and mobile communications widely available to vast numbers of people almost overnight. The combination of these two factors has been instrumental in shaping our societies into what they are today: far more diverse and far more complex than they have ever been. This has engendered a series of new sociocultural and political phenomena (Blommaert, 2012; Blommaert \& Rampton, 2011; Vertovec, 2007). One of these, multilingualism as a normal societal context, has become the norm.

Especially our major cities are rapidly becoming places without distinct majorities. Janssens (2013) reports that 104 languages are spoken in Brussels alone. Increasingly fewer families in Brussels speak only French or Dutch (the official languages) at home, whereas the number of multilingual families is on the rise. In 2006, 6\% of Brussels' residents spoke Arabic. By 2013, this section of the population had increased to $18 \%$. One in ten Brussels residents does not have a firm command of French, Dutch or English (Janssens, 2013). Blommaert and Van Avermaet $(2008$, p. 75) even state, perhaps tentatively, that 405 languages are spoken in Antwerp. The 2011 UK census (Office for National Statistics, 2013) revealed that over 100 languages are spoken in 30 out of the 33 London boroughs. The census also showed that 53 languages that are

\footnotetext{
${ }^{1}$ It should be noted that Pöchhacker (1999) used the term community interpreting here,
} but the definition itself makes clear that public services are in focus. 
considered standard varieties are spoken in London by at least $0.1 \%$ of residents, while it also identified many more non-standard varieties of these languages.

Van Robaeys and Driessens (2011) point to another interesting development. In 2005, 36\% of those seeking assistance at Antwerp's "centres for general wellbeing" (Centra voor Algemeen Welzijn) belonged to an ethniccultural minority and came from one of 105 different countries. By 2009, this percentage had increased to $44 \%$. The service providers at work in these centres named the language barrier as one of the main obstacles hindering them from carrying out their duties.

Mainly as a result of the economic crisis of recent years, some 400,000 people are homeless or sleep in a shelter in the EU, according to recent numbers cited by the former EU Social Affairs Commissioner Lázló Andor (Andor, 2014). In some cities in Spain and Portugal, for example, the demand for services for the homeless rose by up to $30 \%$ between 2008 and 2013 (FEANTSA, 2014).

Integration programmes and processes that do not take these phenomena of super-diversity and multilingualism into account are bound to fail. Since integration is a two-way process, the host countries must organize themselves to ensure universal access to human rights so that newcomers can participate and thus enjoy their rights and fulfil their duties. Access to these rights is guaranteed through service provision that is (co-)organized and/or (co-)funded by governments. When language or rather the lack of a common language between service provider and client creates a breach in communication, measures need to be taken to close that gap. This is precisely what public service interpreting and translation do. And by doing so, they help sustain stable democracies.

\section{Democracy's inclusive measures}

\subsection{Social justice}

A democratic society expects its institutions to be just and equitable. This does not imply that every setback that an individual encounters should be compensated for by the government, but everyone does have a right to reparation or support when something occurs for which they cannot be held responsible. When an individual does not have access to equal opportunities or when circumstances generate unequal opportunities, the situation should be addressed. Opportunities are not equal by nature or birth, and institutions can and often do structurally favour some to the disadvantage of others (cf. Rawls, 1971). Thus, structural inequality is maintained. Consequently, in order to become just and equitable, a society could establish or reform its institutions so as to draw an increasing number of its 'stakeholders' into 'the system', allowing everyone to benefit from and contribute to this system.

\subsection{Access as a social strategy}

The swell of urban areas through $19^{\text {th }}$ century urbanization, immigration and mobility between countries within Europe created a situation of extreme physical proximity among people living in certain areas. This inevitably shaped a context of mutual functional dependency among these people (De Swaan, 1988). It suffices when one inhabitant falls ill with a contagious disease that many others risk contracting the same illness. Contamination by an illness likely to cause death (such as cholera) objectively called for measures to neutralize contagion as an external effect of urban proximity and functional dependency. Such remedies, as well as measures to prevent epidemics, can only be fully effective if they are made applicable to all and are, therefore, accessible to all. Thus, clean streets, potable tap water, efficient drainage and sewage systems, 
and access to health care for most (if not all) inhabitants of Western Europe was the slowly attained result of the recognition by policy-makers, social activists, and individual citizens that collective dangers had to be eliminated by all for all if they were to yield lasting effects. In short, access to (semi-)public services fulfils needs by guaranteeing rights (such as free or inexpensive access to running water) and by imposing duties (to pay taxes) within a given community.

Physical proximity and functional interdependency relations remain key characteristics of present-day urban environments in Europe. Healthcare issues (e.g. avian flu, Ebola) are still more likely to have severe consequences in builtup areas than in less densely populated regions. However, these no longer pose the greatest challenge. More than ever before the effects of global migration are felt locally, in countries, cities, towns, districts, neighbourhoods, streets and homes. As a result, local community life and cohabitation patterns are increasingly being determined by global factors. This generates a potential breeding ground for social friction that may - socially, economically and linguistically - be perceived as a consequence of the physical proximity among people with different behavioural patterns, habits and morals. The influx of a wide range of newcomers can be felt to undermine a structured and thus secure sense of the world.

In communities characterized by ethnic, cultural and linguistic diversity, public interpretation and translation services are instrumental in equipping all sorts of public service providers (such as local authority services, schools, employment agencies, hospitals, welfare organizations and child protection agencies) with the tools to deal with the linguistically complex reality of speakers with limited proficiency in the official language(s) of the community. PSIT services thereby help on the one hand to secure full access for all residents to their rights, and on the other hand, communicate to all residents the duties and obligations imposed on them. In more general terms, PSIT can serve as a policy measure to cope with the external effects of mutual functional dependency through physical proximity among the inhabitants of a certain, often urban, area.

\subsection{PSIT as an instrument to help ensure democracy}

Democracy is not merely the final point at the end of a process that started somewhere in the past and has now reached its fulfilment. Genuine democracies are continuously undergoing processes of democratization, and as a consequence, society (and its public facilities or 'goods') can be made available to an ever-increasing number of its people. By (co-)organizing and (co-)funding public service provision, democratic governments ensure access to fundamental rights. Schools, healthcare, employment agencies, social welfare organizations, youth care programmes and the like are in that respect materialized human rights, as they have taken on a material shape and have been made accessible to the public.

In the super-diverse, multilingual society of the $21^{\text {st }}$ century, public services, and the human rights they safeguard, should also be accessible to "the new dwellers of our increasingly complex social constellations" (Rillof, Van Praet, \& De Wilde, 2014, p. 264). This entails finding ways to overcome the language-related thresholds that are still in place between public services and some of their potential target groups. After all, "[s]ervice provision for everyone implies communication with everyone" (Rillof et al., 2014, p. 264).

Across Europe some supranational, national and regional legislation as well as legislative frameworks explicitly and formally state that language cannot be an obstacle to (at least some) semi-public or public service provision, or that instruments must be provided to ensure access for all. In Flanders (the northern region of Belgium), for example, a Decree on Integration was passed by Parliament in June 2013 (Decreet betreffende het Vlaamse integratie- en 
inburgeringsbeleid, 2013). ${ }^{2}$ Chapter VI Section 4 of this decree explicitly draws attention to public service interpreting and translation, both delimiting the field (in terms of definitions and goals) and sketching a framework for quality assurance (e.g. certification, a central register).

On a supranational level, the International Covenant on Economic, Social and Cultural Rights, a treaty adopted by the UN General Assembly in 1966 and later ratified by over 150 countries worldwide, states that: "The States Parties to the present Covenant recognize the right of everyone to the enjoyment of the highest attainable standard of physical and mental health" (Art. 12 par. 1), and that they pledge " $[t]$ he creation of conditions which would assure to all medical service and medical attention in the event of sickness" (Art. 12, par. 2). In 2000, a committee of the World Health Organization drafted an elaborate comment on the Covenant, including the observation that "the Covenant proscribes any discrimination in access to health care and underlying determinants of health, as well as to means and entitlements for their procurement on the grounds of race, colour, sex, language (...)" (Committee on Economic, Social and Cultural Rights, 2000). These words clearly mirror the Charter of Fundamental Rights of the European Union (2000), which prohibits any discrimination based on any grounds, explicitly including language (Art. 21).

In spite of these commendable legislative initiatives it remains to be seen what structural measures of language or communication support will be taken or will continue to exist in times when governments are trying to come to terms with budget deficits.

\section{ENPSIT}

\subsection{From $a$ European Network to the European Network for PSIT $(\text { ENPSIT })^{3}$}

Only one of the many PSIT domains has so far been regulated by an EU Directive, viz. Directive 2010/64/EU on the right to interpretation and translation in criminal proceedings. Given the context outlined above, this is clearly insufficient to guarantee universal access to public services in EU member states. Taking this concern as their starting point, representatives of some 25 stakeholder organizations met at the Committee of the Regions in Brussels in October 2013. Their prime aim was to look into potential strategies to help prepare clear policy at both member state and European Commission levels. An additional objective was to investigate how PSIT service provision and its practice in Europe can be further professionalized. One possible route in this respect would be to establish EU standards and practices for training, testing and accreditation in PSIT.

In April 2014 the informal network decided to formalize its commitment to these basic goals and become a formal and structured organization: the European Network for Public Service Interpreting and Translation (ENPSIT). As a formal, legal entity it can unreservedly engage in a dialogue with EU and member state policy makers, while efficiently preparing and carrying out all actions it deems fit.

\subsubsection{ENPSIT's objectives}

The ENPSIT objectives are drawn from its Constitution. ENPSIT takes within its scope the domain of interpreting and translation for public services in their broadest sense, involving spoken, written or sign languages, in settings or sectors of inter alia social services, health care, the judiciary, police, education, welfare, child and youth care, asylum and refugee procedures, and victim

\footnotetext{
${ }^{2}$ In English: Decree on the Flemish Policy on Integration and Civic Integration.

${ }^{3}$ For more information on ENPSIT: http://www.enpsit.eu and info@enpsit.eu.

Translation \& Interpreting Vol 7 No 3 (2015)
} 
support services. In general terms, ENPSIT is committed to the advancement of Public Service Interpreting and Translation. It aims to fulfil its mandate by:

- promoting the establishment of standards that guide the practice of PSIT;

- encouraging and sharing research in the field of PSIT;

- advancing educational and training provisions and requirements for PSIT;

- gaining the support of the European Commission for the provision of funding of PSIT and PSIT-related activities including training, accreditation and working conditions;

- advocating the provision of professional interpreting and translation services in PSIT settings;

- liaising with organizations and service providers on issues of relevance to PSIT;

- encouraging the development of local, regional, national, European and international networks of public service interpreters, translators, providers, trainers, testers and researchers, and their organizations or associations.

ENPSIT seeks to influence EU and national policy. As it would be impracticable to target each national (and in some cases sub-national) government in every EU member state separately, ENPSIT first and foremost directs its attention to the European level. To that end, it has formulated the following recommendations for the EU with a view to influencing national policies:

- recognition of PSIT as a vital aspect of an EU integration policy that stands for equal rights and treatment, equal opportunities and diversity;

- guaranteeing the (statutory) right to high-quality language assistance in a social context, including public service provision, in all EU member states;

- implementation of quality standards for PSIT in the EU;

- recognition and funding of PSIT services by EU institutions, EU member states, regional and local authorities and public service institutions;

- $\quad$ support of consultation and partnership structures at various levels (international, EU, national and regional).

These recommendations have been taken almost in their entirety from the "Political Recommendations for the Sector of Social Interpreting and Translation", formulated in 2007 under the auspices of the now obsolete Belgian federal body for public interpreting and translation (FOSOVETCOFETIS, 2007). In ENPSIT's initial phase the text was adopted as a starting point, and the key elements - the above five recommendations - were later integrated in the ENPSIT Constitution.

\subsection{ENPSIT's action plan}

ENPSIT has developed an action plan that spans four broad domains. Firstly, like any fledgling organization it has to consolidate itself as an efficient organization with a manageable structure and transparent lines of communication. To that end it has set up thematic working groups for each of the five domains, assigned responsibilities to specific Board members and it is in the process of establishing a secretariat. 
Secondly, ENPSIT is turning its attention to data collection. Much PSITrelated research ${ }^{4}$ has been conducted during past decades, but it is scattered geographically as well as across many different (academic and professional) sources and disciplines (e.g. sociology, economics, linguistics, translation and interpreting studies). ENPSIT is now pooling all these data in a repository, where it is to be filed in appropriate digital shelves and listed under such headings as Country, Training, Accreditation, Setting, Type of Mediation, Number of Interpreting Interventions, Cost of Translations, Nature of Service Provision, Indicators of Needs. The chief aim is to have a single database from which information can be drawn to feed all possible ENPSIT initiatives.

Thirdly, ENPSIT needs to develop and advance a strategy to foster policymaking at national and supranational levels. This means that, on the one hand, it has to devise effective networking strategies, and on the other hand, compile a case file in support of the European Commission and member state governments for integrated policy-making initiatives on PSIT. The latter effort should benefit greatly from the work completed in the data collection domain.

The fourth and final broad domain is that of training, assessment and accreditation in PSIT. Adequate PSIT provision rests on the quality of the interpreters and translators, which in its turn should be guaranteed by appropriate training and monitored by measures of quality assurance. Since many of the languages on demand in public service settings are not taught in regular bachelor and masters' programmes in translation or interpreting, organizing training in PSIT faces a particular challenge. Taking existing initiatives as its starting point, ENPSIT aims to (i) develop a professional PSIT competency profile and standard for the EU; (ii) develop and exchange adequate PSIT training, assessment and accreditation programmes in EU member states (whether as one integrated programme or a harmonized set of programmes); and (iii) establish such (a set of) programmes in EU member states. These actions should ultimately raise awareness among public service providers of the crucial role that professional public service interpreters and translators play, an aspect which currently seems to escape their attention (cf. D'Haeyer, 2012; Townsley, 2007).

As should be clear from this brief overview, ENPSIT does not intend to reinvent the wheel. Where adequate initiatives exist, cross-fertilization between different countries and institutions is preferred, as long as the ultimate goal of creating Europe-wide policies and programmes can be attained. ENPSIT, for example, already enjoys a close relationship with the global "council for the development of community interpreting", Critical Link International (CLI), and it intends to carry out its data collection programme in close collaboration with CLI's Research Committee.

\section{Beyond interpreting and translation}

In order to make the goal of "communication with everyone" in service provision settings attainable, service providers have a range of communication support professionals and tools at their disposal (see e.g. Rillof \& Michielsen, 2014; Rillof et al., 2014). The nature of these support mechanisms varies from the widely available advice on how to communicate effectively in the official language (e.g. how to speak and write the official language clearly by, for example, avoiding complex discourse and metaphorical language and building shorter sentences in the active voice) to appealing to public service interpreters and translators. Other facilitators and facilitating instruments include assistance

${ }^{4}$ For an interesting overview of academic research into PSIT, see Vargas Urpi (2012).

Translation \& Interpreting Vol 7 No 3 (2015) 
from intercultural mediators ${ }^{5}$, the use of various forms of visualization (e.g. pictograms, videos), and freely available translation tools (such as Google Translate or MyLanguage Translator) that often yield translations that leave much to be desired but can help service providers to cope in specific communication situations.

In some cases an interdisciplinary approach may have to be adopted. When speech therapists, for example, have a child from a non-official language background referred to them, they are faced not only with the language barrier between them and their client. When working with these children they first need to determine whether the observed problem is due to a language development disorder or rather to a less proficient knowledge of the language. In the former case, special needs education may be called for, whereas in the latter, language acquisition support could suffice. To assist speech therapists in making this assessment, CODE, the expertise centre on learning and child development at Thomas More University College (Antwerp, Belgium) has developed a system that allows language analysts to scroll videotaped samples of speech produced by the child in his or her mother tongue in home settings. In collaboration with the Flemish expertise centre on migration, integration and ethnic-cultural diversity (Kruispunt Migratie-Integratie), CODE has developed a competency profile and training programme for these language analysts, as they require specific skills to aid the speech therapist in making a correct diagnosis (see Blumenthal, Mostaert, \& Loncke, 2013; Mostaert, De Kerf, Vandewalle, \& Schraeyen, 2013).

These and other forms of bridging assistance are available (albeit not always as readily as one might wish, as Valero-Garcés, 2010 demonstrates) and in use today. The ways in which they are integrated into public service procedures are, however, all too often unsystematic (see e.g. Roels et al., 2013). Within a single organization the intensity with which the available instruments are used may differ, depending on the individual staff member. Some service providers in a specific region may use them, while others in the same region do not. As a result, even in today's super-diverse, multilingual society the quality of communication in service provision still hinges upon many factors, many of them coincidental.

If service providers are to be able to develop consistent communication policies that enhance access to their services for all their potential clients, two conditions need to be met. Firstly, the bridging instruments that are currently available need to be made available at a single service point. Furthermore, it will not suffice if both policy makers and service providers are simply made aware of the many tools they have at their disposal. They also need easy access to them. In addition, these individual offers should no longer be seen (and used) as separate services, but rather they should be considered an integrated array of communication support services.

Policy makers and public service providers have to develop a coherent approach to the communication needs of their organizations if they want to optimize access to their services and communication with their target groups. Their concept should not only cover the organization's needs from an institutional perspective, but also the needs of its management, its staff who deal with clients of different language backgrounds on a daily basis, the clients themselves, and even the communication support experts they intend to work with. More research into these issues is urgently needed to enable organizations

\footnotetext{
${ }^{5}$ Mediators is a term that has been used in various contexts and with various meanings. For clarity's sake, yet without wanting to engage in a taxonomic debate, we take mediators to be actors who "actively intervene in conversation distributing opportunities to speak, giving the parties space to introduce and deal with particular issues, reinforcing particular roles and identities and promoting successful outcomes" (Gavioli, \& Baraldi, 2011, p. 208). This is clearly a role that goes beyond our definition of interpreting.
} 
to integrate all the above perspectives into a single coherent policy. Van Praet, De Wilde and Rillof (2014) and Rillof et al. (2014) present an example of such exploratory research that led to a communication matrix being developed for Kind \& Gezin, the Flemish agency for the preventive treatment and guidance of young children. In this instance the communicative needs of the organization were identified on the basis of concepts and methodology established in ethnographical and interactional research. Subsequently, a scenario was developed in the form of a matrix that takes staff through all the steps of a familiar procedure, indicating what decisions in terms of communication are to be taken in each step and what factors need to be taken into account while doing so. (See Rillof, Van Praet, \& De Wilde, 2015 for a comprehensive account of how the matrix was developed.)

\section{Conclusion}

The world has evolved into a super-diverse environment, and this situation will not change. One issue today's societies must address is that of communication between service providers and their clients, which is by definition a multilingual environment. If we want to integrate every member of our society into our society, and thus create more 'us' and 'we' through an inclusive approach, then we must develop an integrated array of instruments that supports and sustains communication at all levels. Consequently, these instruments and, not least, public service interpreting and translation should become commonplace. All too often do service providers and policy makers believe that as long as clients in a public service setting make an effort to learn the official language in which communication is meant to be conducted these clients will manage to get by. Many non-native speakers of such an official language indeed make this effort, but does it suffice? Quite a few public service contexts require clients to understand what the Common European Framework of Reference for Languages (CEFRL) describes as demanding texts, typical of the highest proficiency levels. Attaining these takes years of intensive study and practice. Meanwhile clients for which the official language in public service encounters is their second, third or even fourth language indeed try to get by. They often use as much of the language as they can, and revert to coping strategies such as code-switching and polylanguaging (cf. Jørgensen, Karrebæk, Madsen, \& Møller, 2011) - i.e. using features of a variety of languages they are more or less familiar with. This may give service providers the impression that communication is not impaired by language barriers, thereby ignoring the possibility that their interlocutor may not have been able to grasp or convey details and subtleties in what was said although these may be of vital importance to the client. The right to interpreting and translation in legal settings has been recognised on a European level through Directive 2010/64/EU. ENPSIT has taken on the mission to raise awareness among policymakers that the right to a fair trial is just one of many human rights that can only be guaranteed if communication between public service providers and all members of society is optimized, and that the directive on legal interpreting and translation ought to be extended to include all public service settings if we want to shape societies that are genuinely fair and equitable.

\section{References}

Andor, L. (2014). Statement of Commissioner László Andor on World Homeless Day. Retrieved from http://europa.eu/rapid/press-release_STATEMENT-14-311_en. htm (last accessed 19 February 2015). 
Bancroft, M. A., Bendana, L., Bruggeman, J., \& Feuerle, L. (2013). Interpreting in the gray zone: Where community and legal interpreting intersect. Translation \& Interpreting, 5(1): 94-113.

Blommaert, J. (2012). Citizenship, language \& superdiversity: Towards complexity. Working Papers in Urban Language and Literacies 95. Retrieved from http://www.kcl.ac.uk/sspp/departments/education/research/ldc/publications/work ingpapers/abstracts/WP095-Citizenship,-language--superdiversity-Towardscomplexity-.aspx (last accessed 19 February 2015).

Blommaert, J., \& Rampton, B. (2011). Language and superdiversity. Diversities, 13(2), $1-21$.

Blommaert, J., \& Van Avermaet, P. (2008). Taal, onderwijs en de samenleving. De kloof tussen beleid en realiteit. Antwerpen: Epo.

Blumenthal, M., Mostaert, C., \& Loncke, M. (2013). Taalstoornissen bij meertalige kinderen. In H. Bot (Ed.), Taalbarrières in de zorg. Over tolkenbeleid en tolken met beleid (pp. 117-127). Assen: Van Gorcum.

Brodsky, J. (1988, January 21). The condition we call exile. The New York Review of Books, p. 16.

Charter of Fundamental Rights of the European Union. (2000, December 12). Retrieved from http://www.europarl.europa.eu/charter/pdf/text_en.pdf (last accessed 17 February 2015).

Committee on Economic, Social and Cultural Rights. (2000). Substantive issues arising in the implementation of the international covenant on economic, social and cultural rights. General comment $n^{\circ}$ 14. Retrieved from http://apps.who.int/ disasters/repo/13849_files/o/UN_human_rights.htm (last accessed 19 February 2015).

Decreet betreffende het Vlaamse integratie- en inburgeringsbeleid. (2013, June 7). Retrieved from http://www.codex.vlaanderen.be/Portals/Codex/documenten/102 3121.html (last accessed 19 February 2015).

De Swaan, A. (1988). In care of the state. Health care, education and welfare in Europe and the USA in the Modern Era. Oxford: Oxford University Press.

D'Hayer, D. (2012). Public Service Interpreting and Translation: Moving towards a (virtual) community of practice. Meta, 57(1), 235-247.

Directive 2010/64/EU of the European Parliament and of the Council of 20 October 2010 on the right to interpretation and translation in criminal proceedings. (2010, October 20). Retrieved from http://eur-lex.europa.eu/LexUriServ/LexUri Serv.do?uri=OJ:L:2010:280:0001:0007:en:PDF (last accessed 19 February 2015).

ENPSIT. (2014, April 2). ENPSIT Constitution. Retrieved from http://www.enpsit.eu (last accessed 19 February 2015).

FEANTSA. (2014). Confronting homelessness in the framework of the European semester 2014. A FEANTSA monitoring report. Brussels: FEANTSA. Retrieved from http://www.feantsa.org/spip.php?rubrique171\&lang=en (last accessed 19 February 2015).

FOSOVET-COFETIS. (2007). Political recommendations for the sector of social interpreting and translation. Brussels: FOSOVET-COFETIS. International covenant on economic, social and cultural rights (1966, December 16). Retrieved from http://www.ohchr.org/EN/ProfessionalInterest/Pages/CESCR.asp x (last accessed 19 February 2015).

Gavioli, L., \& Baraldi, C. (2011). Interpreter-mediated interaction in healthcare and legal settings. Talk organization, context and the achievement of intercultural communication. Interpreting 13(2), 205-233.

Janssens, R. (2013). Meertaligheid als cement van de stedelijke samenleving. Een analyse van de Brusselse taalsituatie op basis van Taalbarometer 3. Brussel: VUB Press.

Jørgensen, J. N., Karrebæk, M. S., Madsen, L. M., \& Møller, J. S. (2011). Polylanguaging in superdiversity. Diversities, 13(2), 22-37.

Mostaert, C., De Kerf, E., Vandewalle, E., \& Schraeyen, K. (2013). Taaldiagnostiek bij meertalige kinderen: een case-study. Logopedie 4(26), 73-84.

Pöchhacker, F. (1999). Getting organized: The evolution of community interpreting. Interpreting, 4(1), 125-140.

Rawls, J. (1971). A theory of justice. Cambridge Mass., USA: Harvard University Press.

Rillof, P., \& Michielsen, J. (2014). Mind the gap. Ongelijke toegang tot communicatie: motor voor een verdeelde samenleving. In M. Petrovic, F. Ravijts \& E. Roger 
(Eds.), Migratiemaatschappij. 20 stemmen over samenleven in diversiteit (pp. 117-133). Leuven: Acco.

Rillof, P., Van Praet, E., \& De Wilde, J. (2014). The communication matrix. Beating Babel: Coping with multilingual service encounters. In C. Valero Garcés (Ed.), (Re)considerando Ética e ideología en situaciones de conflicto. (Re)visiting ethics and ideology in situations of conflict (pp. 263-269). Alcalá de Henares: UAH Universidad de Alcalá.

Rillof, P., Van Praet, E., \& De Wilde, J. (2015). Eindrapport Communicatiematrix Kind en Gezin. Brussel: Agentschap Integratie en Inburgering. Retrieved from http://www.kruispuntmi.be (last accessed 19 February 2015).

Roels, B., Segher, M., De Bisschop, B., Slembrouck, S., Van Avermaet, P., \& Van Herreweghe, M. (2013). Onderzoek naar de inzet en effecten van sociaal tolken en vertalen. Gent: Universiteit Gent. Retrieved from http://www.esf-agentschap. be/sites/default/files/attachments/articles/eindrapport_onderzoek_naar_de_inzet_ en_effecten_van_sociaal_tolken_en_vertalen.pdf (last accessed 19 February 2015).

Taibi, M. (2014). Community interpreting and translation in the Arab World. Babel, $60(1), 52-69$.

Townsley, B. (2007). Interpreting in the UK community: Some reflections on Public Service Interpreting in the UK. Language and Intercultural Communication, 7(2), 163-170.

Office for National Statistics. (2013). 2011 Census data for England and Wales. Retrieved from Nomis, http://www.nomisweb.co.uk/census/2011 (last accessed 19 February 2015).

SIGTIPS. (2011). Special Interest Group on Translation and Interpreting for Public Services: Final Report. Retrieved from http://ec.europa.eu/dgs/scic/docs/ bsigtips_en_final_2011.pdf (last accessed 19 February 2015).

Valero-Garcés C. (2010). The difficult task of gathering information on PSI\&T. Babel, 56(3), 199-218.

Van Praet, E., De Wilde, J., \& Rillof, P. (2014). Communicatiematrix voor Kind \& Gezin. In S. Evenepoel, P. Goethals \& L. Jooken (Eds.), Beschouwingen uit een talenhuis: Opstellen over onderwijs en onderzoek in de Vakgroep Vertalen, Tolken en Communicatie aangeboden aan Rita Godyns (pp. 125-132). Gent: Academia Press.

Van Robaeys, B. \& Driessens, K. (2011). Naar een divers-sensitieve en empowerende hulpverlening. In D. Dierckx, J. Vranken, J. Coene \& A. Van Haarlem (Eds.), Armoede en sociale uitsluiting. Jaarboek 2011 (pp. 345-361). Leuven: Acco.

Vargas Urpi, M. (2012). State of the art in Community Interpreting research. Babel, $58(1), 50-72$.

Vertovec, S. (2007). Super-diversity and its implications. Ethnic and Racial Studies, 29(6), 1024-54. 